\title{
THE LEGAL STATUS OF THE PHILIPPINES-AS FIXED BY THE RECENT DECISION OF THE SUPREME COURT IN THE JURY TRIAL CASES.
}

The Supreme Court in the recent Philippine "jury trial" cases laid down the rule that if territory has been legitimately and constitutionally acquired by treaty, conquest, purchase or discovery, while it remains unorganized territory of the United States, Congress has power to adopt all appropriate and suitable means for the proper government of such territory not prohibited by the Constitution and not inconsistent with the fundamental and essential principles of free government.

Not since Chief Justice Marshall decided the great cases in which he enforced the famous doctrine of Implied Powers and established the power of the judiciary to determine the validity of an Act of Congress has there arisen a constitutional question which so vitally affects the nation as the one presented by the cases growing out of the administration of our Insular Possessions. Indeed, it will be observed that there is a similarity between the principles laid down by Marshall and those recently declared by the Supreme Court; the doctrine of Implied Powers in its last analysis being, let the end be legitimate, let it be within the scope of the Constitution, then all means which are appropriate, which are plainly adapted to that end, which are not prohibited, but are consistent with the spirit and letter of the Constitution, are constitutional.

The judgment of the great Chief Justice which established the power of the Supreme Court to declare an Act of Congress null and void because inconsistent with the Constitution defined the powers and marked the limitations of Congress in legislating for the states, whilst the judgment of the court in the recent Philippine cases defined the powers and marked the limitations of Congress in legislating for the territories.

The question raised was not altogether new, but the upheaval of the Spanish war brought it out in sharper and bolder outline than it had formerly appeared. Hitherto the nation had been 
confronted with the administration of territory contiguous, for the most part, to the states, and capable of being settled by people schooled in the arts of self-government. Congress was therefore able to extend substantially all the guaranties of the Constitution to the newiy-acquired territory almost from the date of its acquisition. At the close of the Spanish war, however, we found ourselves in possession of islands lying in the tropics, thousands of miles from our shores, and inhabited by people totally ignorant of the duties and responsibilities of selfgovernment.

It was manifest from the beginning that all of the guaranties of the Constitution could not be extended to these peoples, at least for some time to come, and that, according to traditional standards, they were and would for a long period be unfitted for statehood. The cold fact was that we had come into possession of territory unfitted for statehood which had to be administered by governmental machinery unequipped for colonization.

Two questions arose: one of a purely political character to be determined by the people-the other involving a proposition of law to be determined by the Supreme Court. The general public, who were interested mainly in the political aspect of the matter, included in their considerations many questions of law. And it is correct to say that the question of political expediency obtruded itself upon the attention of the courts and the lawyers in the consideration of the purely legal phase. Nor was this strange.

It was a problem for the statesman as well as the jurist, as was the case in the early days of the Republic, when Marshall was called upon, through judicial interpretation, to give the Constitution a meaning that would enable it to grow with the growth of the country and to become adaptable to the manifold and everchanging needs of a young and progressive Republic.

The political question was, Shall we administer the islands, which have fallen into our hands as a result of the war, or shall we admit our incapacity to meet the situation, and turn them over to some more capable, stouter-hearted nation? The people, speaking through the administration, said, Having put our hands to the plow, we will not turn back. We will meet the responsibilities and execute the trust which the fortunes or fate of war have committed to our hands.

The question of law with which the court had to deal, stated in a simple and popular way, was, How shall Congress legislate for these new and remote territories; as it does for the states, 
or appropriately-that is to say, in accordance with the needs, customs and usages, of the people living in the territories? Technically stated, the question was, Is Congress, in legislating for these new possessions, bound by all the limitations and prohibitions contained in the Constitution, which restrain it in legislating for the states, or may it, in a measure, disregard these limitations and extend to or withhold from the territories certain constitutional guaranties as it sees proper? The countrylike the court-was divided almost equally on the question. The view that the Constitution attached with full force and effect, with all the limitations contained in the Bill of Rights, to the newly-acquired territory the moment the sovereignty of the United States was extended over it, was supported by such eminent jurists and constitutional lawyers as Mr. Justice Harlan, Hon. J. C. Carlisle, Judge George F. Edmunds. They held that Congress, in legislating for the islands, must be restricted by the same limitations and prohibitions which apply to it while it is legislating for the states. This position was combatted by the friends of the administration and others, who made a distinction between the United States proper and the territory belonging to the United States; and contended that there was no good reason why Congress, in legislating for the territories, should extend to the people of the territories constitutional guaranties which were unsuited to their wants; that while Congress was always restrained by certain fundamental principles upon which free government is founded, yet there were certain other rules of government, not fundamental in their nature, which Congress might extend to or withhold from the territories as it sees proper; in short, that Congress, under the Constitution, has the power to adopt a government for our insular possessions which is appropriate and suitable to the wants of the people, provided it is not inconsistent with the fundamental principles of free government.

In the Philippine libel case the issue was squarely and clearly raised. Fred L. Dorr and Edward F. O'Brien, owners and editors of the Manila Freedom, were arrested and brought to trial in Manila on the charge of criminal libel. They demanded a jury trial. This was denied by both the trial court and the Supreme Court of the islands. The case was appealed to the Supreme Court of the United States on the ground that the ruling of the Philippine court was wrong because it violated a right guaranteed by the Constitution. Under the Spanish law, which was in force in the islands at the date of American 
occupation, all trials were conducted by judges. This law had never been changed by military order or act of the commission, and when Congress passed what is known as the "Philippine Government Act' of July 2, Ig02, it extended to the islands all the guaranties contained in the Bill of Rights except the right of trial by jury and the right to bear arms. The case presented the question whether in the absence of a,statute of Congress expressly conferring the right, trial by jury is a necessary incident of judicial procedure in the Philippine Islands. The court decided that the right to acquire territory carries with it the power and obligation to govern it; and that Congress while acting under Article 4. Section 3, of the Constitution, which gives it power to dispose of and make all needful rules and regulations respecting the territory of the United States, is not bound to extend the right of trial by jury to such territory as the Philippine Islands. It also held that the Constitution does not of its own force and without legislation carry such right to territory so situated. The court has held in other cases that the Philippine Islands are territory belonging to the United States. Mr. Justice Day in delivering the opinion of the court reasoned that:

"If the right to trial by jury were a fundamental right which goes wherever the jurisdiction of the United States extends, or if Congress, in framing laws for outlying territory belonging to the United States, was obliged to establish that system by affirmative jegislation, it would follow that, no matter what the needs or capacities of the people, trial by jury, and in no other way, must be forthwith established, although the result may be to work injustice and provoke disturbances rather than to aid the orderly administration of justice. If the United States, impelled by its duty or advantage, shall acquire territory peopled by savages, and of which it may dispose or not hold for ultimate admission to statehood, if this doctrine is sound, it must establish there the trial by jury. To state such a proposition demonstrates the impossibility of carrying it into practice. Again, if the United States shall acquire by treaty the cession of territory having an established system of jurisprudence, where jury trials are unknown, but a method of fair and orderly trial prevails under an acceptable and long-established code, the preference of the people must be disregarded, their established customs ignored and they themselves coerced to accept, in advance of incorporation into the United States, a system of trial unknown to them and unsuited to their needs. We do not think it was intended, in giving power to Congress, to make regulations for the territories, to hamper its exercise with this condition." 
It will be observed that there was but a single constitutional point determined by the court in these cases, viz., the question of the right of trial by jury. But the decision of the court has a meaning far beyond the simple determination of this special question. The significant feature of the decision of the court in these and in the other Insular Cases is the principle or rule of interpretation invoked which lies at the foundation of the judgment of the court. In order to get at the principle underlying the decisions, it is necessary to make clear discrim. inations upon two important points:

First, in regard to the two kinds of territory which make up what Chief Justice Marshall called the "American Empire;" and

Second, with reference to the different character of rights guaranteed by the Constitution.

These discriminations may be found in the opinions of the court, but the latter and more important one has not in terms been laid down as the basis of a rule of constitutional interpretation. The distinction between the states which constitute the Union and the territories outside of the Union which belong to the government is easily made and is one found in the Constitution itself. The Constitution provides in Article 4 that territories as such shall be governed by Congress and before they become states they must be admitted by Congress into the Union. This act is attended with a solemn eeremony of farreaching consequence which changes entirely the legal status of the territory. Laws of a local character cease to operate and the Constitution in its entirety becomes the fundamental law of the land. An indissoluble contract is entered into; an indestructible yoke is imposed.

Whilst this discrimination is clear and easily made, to discriminate between the two classes of rights guaranteed by the Constitution is attended with much greater difficulty.

It was contended, on the one hand, that all the limitations on congressional action contained in the Constitution are fundamental, while the extreme advocates of the other view held that none of them are of such fundamental character that Congress might not transcend them in legislating for the territories. The one side contended that Congress must legislate for the territories just as it legislates for the United States, whilst the other asserted that it might operate in the territories with an absolutely free hand. The rule lies between the extreme limits of the foregoing views. There are undoubtedly some limitations which are not 
fundamental, and it is equally true that there are others which are, and which Congress cannot violate without subverting the very foundations of the Government; so that the true meaning of the finding of the court in the Insular Cases-that is to say, the principle of constitutional construction upon which the decision must rest-is this: that there are certain prohibitions and restrictions contained in the Constitution relating to fundamental rights which go to the very root of the poiver of Congress to act at all, in all places, at all times, and under all circumstances, in the territories as well as in the states. On the other hand, there are other constitutional limitations, not absolute in their nature, which relate to such matters as methods of procedure and forms of judicial trials that do not restrict Congress in the exercise of its power to create local governments and make needful rules and regulations respecting the territories of the United States.

I think the rule as above stated is a fair deduction from the decision of the court in all of the insular cases and contains the true philosophy contained therein, but its formation as such and its final adoption as a rule of constitutional interpretation is reserved for the future.

This being the vital point in the case the question naturally arises, What limitations are fundamental, and what are not fundamental? I shall undertake to answer this question generally and particularly. Generally speaking, those guaranties are fundamental which are essential to the very existence of free government. Those expressed and implied restrictions relating to individual rights without which our form of government could not exist, and which are respected by all modern governments worthy of the name are undoubtedly fundamental. The genius, nature and spirit of free government forbid the violation of such rights at all times, in all places, and under all circumstances, and hence those restrictions relating to them go to the very competency of Congress to act at all. Such rights are guaranteed by the Constitution itself, and the first eight amendments. I would go farther, and say that the general principles of law, reason and justice would guarantee these rights to the people independent of their existence in the amendments of the Constitution known as the "Bill of Rights." If the government, or any branch of it, should undertake to violate these rights it would subvert the principles on which it is based.

The artificial or remedial rights are those which relate to methods and forms of judicial trial and modes of taxation, the extension of suffrage, etc., which can be varied with the needs 
of the people without withholding from them those elemental rights, the enjoyment of which is the essence of free government.

To descend to particulars, I should say, by way of illustration, that the following are fundamental restrictions on congressional action:

(a) A person shall not be deprived of life, liberty or property without due process of law-(a person shall not be condemned before he is heard).

(b) Private property shall not be taken for public use without just compensation.

(c) A person shall worship God according to the dictates of his own conscience.

(d) Freedom of speech or the press shall not be abridged.

(e) No bill of attainder or ex post facto law shall be passed.

$(f)$ No title of nobility shall be granted by the United States, etc. tract.

$(g)$ No law shall be passed impairing the obligation of con-

I should say, on the other hand, that the following limitations are not fundamental, and hence are not binding upon Congress in legislating for the territories of the United States:

(a) In criminal prosecutions, the accused shall enjoy the right to a trial by an impartial jury (he may be tried by a judge and no natural right be violated).

(b) The right of the people to keep and bear arms shall not be infringed.

(c) The right to suffrage.

(d) All duties, imposts and excises shall be uniform throughout the United States.

(c) No person shall be held to answer for a capital or otherwise infamous crime unless on a presentment or indictment by a grand jury.

If I am correct in the foregoing analysis, if the rule as above indicated is the true basis of the finding of the court, the task of the court in passing upon such cases in the future will be to determine what are the natural and what are the artificial rights guaranteed by the Constitution.

In this connection I desire to call attention to the distinction which the court makes between organized and unorganized territory of the United States. The court says in the Insular Cases that territory to which the provisions of the Constitution have been extended by Congress is organized territory, which has been incorporated into the United States, whilst the newlyacquired territory to which the Constitution has not been 
extended is known as unorganized territory of the United States. Following this distinction, the court says that when once the provisions of the Constitution have been extended to the territory by Congress they cannot be withdrawn. I confess that these propositions do not commend themselves to my judgment. In the first place, the organization of a territory belonging to the United States by extending the provisions of the Constitution to it is one of degree, merely. For example, an act of Congress has been passed providing for the government of the Philippine Archipelago in which all the guaranties of the Constitution and the Bill of Rights have been extended to the islands, except two. The question naturally arises, Are the Philippines, under the ruling of the court, organized or unorganized territory of the United States? According to the test they are not yet organized territory, but, as a matter of fact, they are ruled by governmental machinery which Congress has created, and are certainly in a degree organized. The proposition that when the provisions of the Constitution have been once extended to the territories by Congress, they cannot be withdrawn, seems to us to lack the support of sound reasoning. If Congress has the power to withhold a constitutional guaranty from the territories, it certainly has the power to withdraw such guaranty if it be found to be inapplicable and not calculated to subserve the best interest of the people. The power to withhold or extend implies the power to withdraw.

I shall now consider briefly the effect of these decisions upon the growth and development of the country. It will be observed that no time has been devoted to the discussion of the sources of the power of Congress for governing the territories. I deem this unnecessary. It may be derived from either of two sources: First, the power may come from the Constitution itself, which empowers Congress "to make all needful rules and regulations respecting the territory or other property belonging to the United States"; or, second, the right to govern may be the inevitable consequence of the right to acquire territory. The moment sovereignty extends over a territory the obligation is imposed irrespective of constitutional provisions to administer that territory. Whichever may be the source whence the power is derived, the possession of it is unquestioned.

It is curious and interesting to note the opinions of the framers of the Constitution on this phase of the work at the time the Constitution was adopted. Governeur Morris, for 
example, who framed the clause relating to the government of the territories by Congress, in writing to a friend, used the following language:

"I always thought that when we should acquire Canada and Louisiana it would be proper to govern them as provinces, and allow them no voice in our councils. In wording the third section of the fourth article, I went as far as circumstances would permit to establish the exclusion. Candor obliges me to add my belief that had it been more pointedly expressed, a strong opposition would have been made. . . .

"I knew as well then, as I do now, that all North America must at length be annexed to us. Happy indeed if the lust of dominion stop there. It would, therefore, have been perfectly Eutopian to oppose a paper restriction to the violence of popular sentiment in a popular government."*

A casual analysis of these decisions, in the light of the char acter of our people and of the position our country now holds among the nations of the world, produces the conviction that the principle here enforced is bound to play a large part in the development of the nation. If the view of the minority of the court had prevailed, it would have been tantamount to saying that this government shall not go to war because it would be unable, by reason of its structure, to meet the obligations that may result from war. When nations go to war, as all are likely to do some time in their history, they are likely to either cede or acquire territory. Hitherto the results of our wars have been the acquisition of territory.

If an interpretation is given to the Constitution which will result in tying the hands of Congress in the administration of newly-acquired territory, it amounts to saying to the United States: You must not take territory that cannot be inhabited by our own people, and cannot be ultimately incorporated into the Union as a state. This is all very well as a general national policy, but to prescribe it as a rule of law would have the effect of rendering the government impotent in the case of an emergency by denying it one of the attributes of sovereignty and by circumscribing the treaty-making power. When a nation goes to war it must be prepared to meet the emergencies and responsibilities which result from war. Such things cannot be forecasted. In the case of our late war with Spain the unexpected happened. No one dreamed of our taking the Philippines when our war was declared. They came to us as the result of

* 3 Spark's Life of Morris, pp. 185-rg2. 
the destruction of the Spanish fleet in Manila Bay; and after the ratification of the treaty ceding them to the United States it became our duty to administer them. According to the decision of the courts in the Insular Cases, we are enabled to administer them appropriately, and thereby fulfill our obligations to ourselves and to the Philippine people.

The hand of our government is now in the Orient and has been for a number of years. Whilst we stand for justice, fair play and peace among the nations, no one can foretell where this policy may ultimately lead us. It is possible, though improbable, that it may in time lead to war, and in such an event we might be forced to acquire territory in Asia. This acquisition would involve the obligation to administer such territory. Would it be wise to place a construction upon the Constitution which would practically preclude us from meeting such an obligation if it should arise? I do not believe that those who made the Constitution meant to hamper or restrict the nation in meeting its obligations and responsibilities as such. The limitations contained in the first ten amendments to the Constitution were designed for the protection of the people of the states alone. The amendments to the Constitution contain a clear distinction between the United States proper and territory under the jurisdiction of the United States. The first ten amendments refer only to the United States, and were intended to apply to the federal government for the purpose of preventing encroachments upon the rights of the people of the states, whilst the thirteenth and fourteenth amendments apply, in terms, to the territories, and persons within the United States, and to places and persons subject to the jurisdiction of the United States.

I would not be understood as favoring as a national policy the acquisition of territory beyond the seas. I am opposed to such a policy. On the other hand, I can find nothing in the Constitution itself, or in the decisions of the Supreme Court; or in the nature, spirit or history of our institutions which warrants an interpretation that would hamper us in meeting emergencies as they arise.

The Declaration of Independence opens with the statement that, "In the course of human events it has become necessary for us to assume among the powers of the earth the separate and equal station to which the laws of nature entitle us," and concludes with the statement, "As free and independent States they (the United States of America) shall have power to levy 
war, conclude peace, contract alliances, establish commerce, and to do all other acts and things which independent states may of right do."

The Constitution of the United States confers absolutely upon the government of the Union the power of making war and of making treaties, and the power of acquiring territory, either by conquest or treaty. The decisions of the Supreme Court from the days of Chief Justice Marshall to the present time leave no room for doubt that, under the Constitution, the government of the United States, by virtue of its sovereignty, has the full right to acquire territory enjoyed by every other sovereign nation.

It is clear that when our forefathers threw off their allegiance to Great Britain and established a republican government, they meant to call into being a nation endowed with those powers to acquire and govern territory which all independent governments, by virtue of their sovereignty, enjoy.

In the light of these facts, it is not strange or unreasonable that the Supreme Court should declare that the Philippine Archipelago, being territory belonging to the United States, legitimately acquired, may be governed by Congress with a view to the needs, usages, customs and conditions of the inhabitants of such territory, and to that end may be adopted all appropriate means not in violation of those natural and fundamental rights guaranteed by the Constitution, which form the basis of all free government.

Lebbeus R. Wilfley. 